usefulness is necessary. Clearly, even minor degrees of haemolysis should not be overlooked.

${ }^{1}$ Gonen, B, et al, Lancet, 1977, 2, 734.

2 Koenig, R J, et al, New England fournal of Medicine, 1975, 295, 417.

${ }^{3}$ Bunn, H F, et al, fournal of Clinical Investigation, 1976, 57, 1652.

${ }^{4}$ Davies, M G, Marks, R, and Nuki, G, Quarterly fournal of Medicine, $1978,47,221$.

${ }^{5}$ Svendsen, P A, et al, Lancet, 1979, 1, 1142

(Accepted 14 August 1979)

Departments of Medicine and Haematology, Southern General Hospital, Glasgow G51 4TF

C M KESSON, MRCP, senior registrar

J W WHITELAW, FRCPED, FRCPATH, consultant haematologist

J T IRELAND, MD, FRCPED, consultant physician

\section{Oral mannitol: a simple and effective bowel preparation for barium enema}

Bowel preparation for a barium enema usually includes inconvenient restriction of diet and unpleasant nights of diarrhoea and abdominal pain after taking cathartics. The subsequent radiographs are not always of the highest quality and sometimes have to be repeated. Since the osmotic diarrhoea induced by oral manitol affords excellent preparation for colonoscopy ${ }^{1}$ and is usually well tolerated we thought it might also be a convenient and effective method of preparing the bowel for barium enema. We therefore carried out a trial comparing mannitol with our routine preparation.

\section{Patients, methods, and results}

Forty consecutive patients referred from medical and surgical outpatient departments and general practitioners entered the trial. They received routine preparation (preparation A) or mannitol (preparation B) according to whether they had their barium enema on odd or even number days of the trial. They were all examined during afternoon sessions by the same radiologist (ANK) using an identical technique. Preparation A comprised a lowresidue diet for three days before examination with instructions to drink an extra pint $(0.61)$ of fluid each day. At $9 \mathrm{pm}$ on the evening before the enema $20 \mathrm{~g}$ magnesium sulphate dissolved in water was taken by mouth, followed at $11 \mathrm{pm}$ by $45 \mathrm{ml}$ castor oil and at 8 am the next morning by the insertion of a $10-\mathrm{mg}$ bisacodyl suppository. With preparation $\mathrm{B}$ diet was unrestricted. Patients were instructed to drink at $7.30 \mathrm{am}$ on the day of the examination one litre of $10 \%$ mannitol solution (BP), iced and mixed with fruit juice, within 30 minutes, and subsequently to drink as much fluid as they wished. On arrival at the radiology department each patient completed a questionnaire about bowel action and side effects associated with their preparation. A conventional barium enema followed by drainage of barium and replacement with air was performed and seven similar views taken in each case. The radiographs were then seen by a consultant radiologist who had no knowledge of the preparation employed and assessed as follows: grade I, no visible faeces; grade II, minimal faecal matter coating the bowel wall; grade III, small amount of material within the lumen but not affecting the diagnostic value of the examination; grade IV, gross faecal matter such that the films were not diagnostic-for example, small polyps could not be excluded. The mucosal coating was then graded as good, adequate, or poor and the films scrutinised for lesions.

The table shows that the quality of the radiographs obtained after mannitol preparation were significantly better than those after routine techniques $\left(\mathbf{P}<0.01\right.$ by the $\chi^{2}$ test with Yates modification for small frequencies). All patients had diarrhoea of about equal frequency in the two groups. Though the numbers were small, there were more side effects associated with preparation A. No patients had incontinence but more preparation A

Quality of bowel preparation for barium enema

\begin{tabular}{|c|c|c|c|c|c|c|c|}
\hline \multirow{3}{*}{ Preparation } & \multicolumn{7}{|c|}{ No of patients } \\
\hline & \multicolumn{4}{|c|}{ Clearance grade } & \multicolumn{3}{|c|}{ Coating } \\
\hline & I & II & III & IV & Good & Adequate & Poor \\
\hline $\begin{array}{l}\mathrm{A} \\
\mathrm{B}\end{array}$ & $\begin{array}{r}3 \\
14\end{array}$ & $\begin{array}{l}7 \\
2\end{array}$ & $\begin{array}{l}6 \\
1\end{array}$ & $\begin{array}{l}7 \\
0\end{array}$ & $\begin{array}{l}14 \\
16\end{array}$ & $\begin{array}{l}7 \\
2\end{array}$ & $\begin{array}{l}2 \\
0\end{array}$ \\
\hline
\end{tabular}

patients had considerable urgency. Nausea and vomiting were also more common after routine preparation, though equal numbers had abdominal pain.

\section{Comment}

Although rectal washouts and enemas can be given to outpatients, 2 the lack of any clearcut benefit ${ }^{34}$ and the inconvenience and discomfort to the patient has prompted many radiology departments to prepare the colon by methods similar to our conventional method. Preparation with mannitol is quick and sodium loss is only moderate. We therefore think it the preparation of choice for both quality of radiograph and comfort of the patient.

We thank Dr C D Holdsworth for his help with this manuscript and Dr P Ward for reporting on the radiographs.

\author{
1 Williams, C, Symposium on Colonoscopy, Newcastle, 1979. \\ ${ }^{2}$ Miller, R E, Gastroenterology, 1976, 70, 289. \\ 3 Barnes, M R, Radiology, 1968, 91, 948. \\ 4 Irwin, G A L, Shields, J E, and Wolffe, W, Gastroenterology, 1974, 67, 47. \\ 5 James, J W, Evans, R A, British Medical fournal, 1970, 1, 463.
}

(Accepted 20 April 1979)

Hallamshire Hospital, Sheffield S10 2JF

K R PALMER, MRCP, senior medical registrar (present address: Department of Medicine, Royal Free Hospital, London NW3 2QG) A N KHAN, MRCP, FRCR, senior registrar in radiology

\section{Bacteroides infection in fibroids during the puerperium}

Infection in fibroids is unusual but when it occurs it tends to be in the early puerperium. ${ }^{1}$ We report two puerperal cases of fibroid infection with Bacteroides fragilis, a well-established causative agent of postdelivery endometritis. ${ }^{2}$

\section{Case reports}

Case 1-A 37-year-old primigravida first attended hospital on 17 December 1971 complaining of vaginal bleeding after three months' amenorrhoea. The uterine fundus reached the umbilicus and there were several small fibroids. A pregnancy test was positive. During her pregnancy the fibroids grew rapidly. On 28 June 1972 the fetus died in utero owing to placental insufficiency. Two days later a macerated female infant weighing $2.9 \mathrm{~kg}$ was spontaneously delivered. On manual removal of the retained placenta a huge fibroid mass was found communicating with the uterine cavity along the full length of its left wall. Three days after delivery the patient developed a persistent fever of $38-38 \cdot 5^{\circ} \mathrm{C}$. Ampicillin was given but she developed vomiting and diarrhoea with weight loss and cachectic appearance. Subacute obstruction supervened, and at laparotomy on 22 July a huge sloughing cystic mass was found densely adherent to the peritoneum and the colon. The mass contained 4.51 of brown, faecal-smelling fluid. It was identified as a degenerating fibroid and a hysterectomy was performed. Subsequent recovery was uneventful. Anaerobic culture of the fluid gave a pure growth of $B$ fragilis.

Case 2-A 35-year-old para $1+0$ first attended hospital on 17 July 1978 at 11 weeks' gestation. An ultrasonic scan showed a normal gestation sac but the isthmus of the uterus was expanded by a fibroid $8 \mathrm{~cm}$ in diameter. Her further antenatal care was uneventful except that the fibroid grew to cause an unstable lie of the fetus. Spontaneous labour began at 38 weeks' gestation on 29 January 1979 . At caesarean section a fibroid about $18 \mathrm{~cm}$ in diameter was found on the left side of the lower segment. A lower segment operation was possible and a healthy baby girl weighing $2.9 \mathrm{~kg}$ was delivered. Eight days after delivery the patient developed a fever of $37.8^{\circ} \mathrm{C}$ rising to $38.6^{\circ} \mathrm{C}$. A scan showed cavitation in the fibroid mass. The next day she passed a large quantity of necrotic fibroid tissue which produced on anaerobic culture a pure growth of $B$ fragilis. The patient was treated with metronidazole. Recovery was uneventful apart from the passage of further pieces of necrotic fibroid tissue over several days. On 2 May 1979 the patient was asymptomatic but the uterus was the size of a 14-week gestation owing to multiple small fibroids.

\section{Comment}

After delivery fibroids have a greatly diminished blood supply and tend to undergo ischaemic degeneration. This offers an ideal culture 
medium to anaerobic organisms that quickly invade the uterine cavity in the early puerperium. ${ }^{3}$ When a patient known to have fibroids develops symptoms and signs of endometritis after delivery she should be treated initially with antibiotics appropriate to anaerobic organisms. In some cases, such as in our case 1 , specimens for culture cannot be obtained. Treatment should then be started on suspicion of anaerobic infection alone.

We thank Professor W Gavin for allowing us to report case 1.

${ }^{1}$ Jeffcoate, T N A, in Principles of Gynaecology, 4th edn, p 426. London, Butterworth, 1975.

${ }^{2}$ Finegold, S M, in Anaerobic Bacteria in Human Disease, p 363. New York, Academic Press, 1977.

${ }^{3}$ Willis, A T, in Anaerobic Bacteriology: Clinical and Laboratory Practice, 3rd edn, p 215. London, Butterworth, 1977.

(Accepted 20 August 1979)

Department of Gynaecology and Obstetrics, Royal Infirmary, Huddersfield HD3 3EA

J G FEENEY, MB, MRCOG, consultant obstetrician and gynaecologist

$S$ B BASU, MD, senior house officer

\section{Prazosin and priapism}

Priapism, persistent painful erection of the penis, is rare but has many causes including drugs, particularly the phenothiazines. ${ }^{1}$ How phenothiazines cause priapism is not clear but has been attributed to their ability to block alpha-adrenergic receptors. Parasympathetic dominance seems to encourage erection, and sympathetic blockade seems to inhibit ejaculation and detumescence. ${ }^{1}$ We report on two patients who developed priapism while taking prazosin for hypertension. This drug, the first of a new class of antihypertensive agents, interferes with alpha-adrenergic function at the postsynaptic level. ${ }^{2}$

\section{Case reports}

Case 1-A 43-year-old West Indian was found to be hypertensive in 1976 and treated initially with propranolol $160 \mathrm{mg}$ and hydrallazine $25 \mathrm{mg}$ both thrice daily. Because his blood pressure was not well controlled prazosin was substituted for hydrallazine at a dose of $6 \mathrm{mg}$ daily and gradually increased to $20 \mathrm{mg}$ daily. Three months after starting prazosin the patient experienced the first of three episodes of priapism, which lasted for six hours and which he did not report to his doctor. He had no history of genitourinary disease. He was admitted with a painful sustained erection that had lasted for 30 hours. Examination showed an erect penis with tense and tender corpora cavernosa but flaccid glans and corpus spongiosum. The scrotal contents and the prostate were normal. The abdomen and the central nervous system were also normal. His blood pressure was $180 / 120 \mathrm{~mm} \mathrm{Hg}$. Investigations showed: haemoglobin $16.2 \mathrm{~g} / \mathrm{dl}$; white cell count $11.6 \times 10^{9} / 1$ with a normal differential count; erythrocyte sedimentation rate $5 \mathrm{~mm}$ in the first hour; sickle-cell trait on haemoglobin eletrophoresis; blood urea concentration $2.8 \mathrm{mmol} / 1(16.9 \mathrm{mg} / 100 \mathrm{ml})$; liver function tests normal; syphilis serology negative; no protein, casts, or cells on urine analysis, and the urine was sterile. The patient was initially but unsuccessfully treated with ancrod. Subsequently the corpora cavernosa were drained and the penis became flaccid. His postoperative course was complicated by pulmonary infarction. His blood pressure was later adequately controlled with atenolol and bendrofluazide. The patient was still impotent after four months.

Case 2-A 43-year-old West Indian was found to be hypertensive in 1977. He was started on prazosin treatment in December 1977 at a dose of $1.5 \mathrm{mg}$ daily, and this was increased gradually to $18 \mathrm{mg}$ daily by the end of January. In early February the patient reported that he had on three separate occasions experienced painful spontaneous erections lasting up to nine hours. He had no history of genitourinary disease, and physical examination was unremarkable. Routine blood tests were normal, the sickle-cell screening test was negative, and haemoglobin electrophoresis was normal. Urine analysis showed 5-10 white blood cells in a high-power field, but no protein or casts; the urine was sterile. Intravenous urography was normal. The prazosin was stopped, and his blood pressure was controlled with propranolol, triamterene, and hydrochlorothiazide. In the 18 months since prazosin was stopped priapism has not recurred.

\section{Comment}

Sexual dysfunction, particularly impotence and failure of ejaculation, is a well-recognised side effect of some antihypertensive drugs that interfere with autonomic function. Priapism has been described in patients taking guanethidine, and the direct-acting vasodilator hydrallazine. ${ }^{3}$ Sexual difficulties are said to be rare with prazosin although "congestion of (the) penis" has been attributed to the drug in one case. ${ }^{4}$ Priapism associated with prazosin has not previously been reported.

Prazosin is thought to produce alpha-adrenergic blockade in a different way from the classical alpha-blockers phenoxybenzamine and phentolamine. $^{2}$ The unusual side effects of prazosin, frequency of micturition and incontinence of urine, have been attributed to this alpha-blocking action. ${ }^{5}$ We now consider priapism a potential hazard of treatment with prazosin.

The weak association of sickle-cell trait and priapism may have contributed to the irreversible priapism in case 1. Prazosin should perhaps be avoided in men with the sickle-cell trait.

1 Dorman, B W, and Schmidt, J D, fournal of Urology, 1976, 116, 51.

2 Graham, R M, and Pettinger, W A, New England fournal of Medicine, $1979,300,232$.

${ }^{3}$ Rubin, S O, Scandinavian fournal of Urology and Nephrology, 1968, 2, 81.

4 Prazosin Research Group in Japan, Medical fournal of Australia, 1977, Suppl 2, p 38.

5 Thien, T H, et al, British Medical fournal, 1978, 1, 622.

(Accepted 21 August 1979)

\section{Whittington Hospital, London N19 5NF}

A K BHALLA, BSC, MRCP, senior house officer

B I HOFFBRAND, DM, FRCP, consultant physician

P S PHATAK, MB, FRCS, consultant surgeon

East Birmingham Hospital, Birmingham B9 5ST

S R REUBEN, MB, MRCP, consultant cardiologist

\section{Vancouver style}

All manuscripts submitted to the $B M F$ from now on should conform to the uniform requirements for manuscripts submitted to biomedical journals (known as the Vancouver style).

The $B M \mathcal{F}$, together with many other international biomedical journals, has agreed to accept articles prepared in accordance with the Vancouver style and will be introducing the system from January 1980. The style (described in full in BMF, 24 February, p 532) is intended to standardise requirements for authors and covers text format, presentation of methods and results, use of SI units, and the form of tables and illustrations. All the participating journals have also agreed to introduce a standard form of references.

In future references to papers submitted to the $B M \mathcal{F}$ should include: the names of all authors if there are fewer than seven or, if there are more, the first three followed by et al; the title of journal articles or book chapters; the titles of journals abbreviated according to the style of Index Medicus; and the first and final page numbers of the article or chapter.

Examples of common forms of references are:

${ }^{1}$ International Steering Committee of Medical Editors. Uniform requirements for manuscripts submitted to biomedical journals. Br Med f 1979;1:532-5.

2 Soter NA, Wasserman SI, Austen KF. Cold urticaria: release into the circulation of histamine and eosinophil chemotactic factor of anaphylaxis during cold challenge. $N$ Engl f Med 1976;294:687-90.

3 Weinstein L, Swartz MN. Pathogenic properties of invading microorganisms. In: Sodeman WA Jr, Sodeman WA, eds. Pathologic physiology: mechanisms of disease. Philadelphia: W B Saunders, $1974: 457-72$.

$\mathrm{Up}$ to the beginning of October some 100 journals had agreed to accept articles in the Vancouver style, and a full list will be printed early in 1980 . 